DOI:10.17951/h.2016.50.3.85

\begin{tabular}{lcc}
\hline \multicolumn{2}{c}{ A N N A L E S } \\
UNIVERSITATIS MARIAE CURIE-SKŁODOWSKA \\
LUBLIN - POLONIA \\
VOL. L, 3 & SECTIOH H \\
\hline
\end{tabular}

University of Economics in Katowice. Faculty of Finance and Insurance

JACEK KUCZOWIC, BARTŁOMIEJ JABŁOŃSKI

kuczowic@ue.katowice.pl,bartlomiejjablonski@o2.pl

\title{
Identification and Analysis of Financial Determinants of the Dividend Policy of Companies Quoted on Warsaw Stock Exchange in 2002-2013
}

Identyfikacja i analiza uwarunkowań finansowych polityki dywidend spółek notowanych na GPW w latach 2002-2013

Keywords: dividends; payout policy; financial report; company's finances; Pearson's linear correlation coefficient

Slowa kluczowe: polityka dywidendy; wypłata; sprawozdanie finansowe; finanse firmy; współczynnik korelacji liniowej Pearsona

JEL Code: G32; G35; C02

\section{Introduction}

The previous research on companies quoted on developed as well as emerging capital markets demonstrates a variety of factors which can determine the payout policy that is the dividend payout, share redemption and cancellations. The subject literature adopts a division into micro- and macro-economic determinants of the dividend policy. The research pertaining to the former group comprises an analysis of relations between the dividend payout and effective investment projects, a company's life cycle, costs of emission of new shares, volumes of cash flow, cash accessibility or profit stability. The macro-economic determinants of the dividend payout, on the other hand, are believed to be the economic situation of the country, dynamism of 
the gross domestic product, the legal system in force, inflation or differences in the taxation of dividends towards the taxation of capital gains.

The diversity of factors which might influence the payout of dividends depicts the scale of possible considerations. The efforts of researchers are directed towards the goal of indicating the properties of companies which pay out dividends. The subject of studies conducted by the authors is the identification of determinants of the dividend payout by publicly held corporations quoted on Warsaw Stock Exchange. The objective of this article is to present the results of the initial stage of research, aiming at the identification and clarification of relationships between financial parameters describing a company's operations and the paid-out dividends. The subject of considerations contained herein is an analysis of the inclination of companies to pay out dividends depending on their financial and property-related standing.

The prevailing part of the analyses of determinants of the dividend policy presented in the subject literature pertains to developed capital markets, in particular in the USA. Studies that should be recognized as the most significant in this respect are the ones carried out by J. Lintner [1956], E.F. Fama and K.F. French [2001], H. DeAngelo, L. DeAngelo and D.J. Skinner [2000], H. DeAngelo, L. DeAngelo and R.M. Stulz [2006], J.H. von Eije and W.L. Meggison [2006], L. Bulan and N. Subramanian [2009]. They point out to the relationships suggesting that the larger the company and the higher the profit generated by the company (as well as accumulated profit) and its profitability, the bigger the chances for a dividend to be paid out. Furthermore, this research confirms a concentration of dividend payouts during the previous years, i.e. the increase of the sum of the paid-out dividends with a simultaneous drop in the number of companies paying them out.

A relatively short period of the operation of Warsaw Stock Exchange in Poland is responsible for the fact that the determinants of the dividend policy have not been thoroughly examined, yet. The study of corporations quoted on Warsaw Stock Exchange in Warsaw conducted by R. Tuzimek [2013], B. Horbaczewska [2012], M. Kowerski [2011] and M. Sierpińska [1999] confirm that corporations which pay out dividends have higher profitability, exhibit higher fluidity, use the financial leverage to a lesser extent and have lower investment capacities. Furthermore, it also suggests that the economic situation in the country in the previous year has a decisive impact on the decisions to pay out dividends in the base year; interestingly enough, companies exhibiting negative values of the $\mathrm{P} / \mathrm{E}$ ratio (i.e. which generate losses) which pay out dividends are - contrary to the principles of economics - evaluated positively. Additionally, the research conducted on Warsaw Stock Exchange for the period 1991-2009 by B. Jabłoński [2010] points out that the portfolios consisting of dividend companies exhibit a higher one-year stock return than portfolios consisting of companies which are appointed according to the same principles, but which do not pay out dividends.

On the basis of theories and research results presented in the subject literature and on the basis of the analyses and research on dividend companies carried out so far by the research team, hypotheses subject to verification were formulated pertaining to 
the relationship between the paid-out dividend and the selected financial parameters of companies' operations in four domains of dependence:

H1: There is a statistically significant correlation between the paid-out dividend and the value of the financial parameters in the year for which the dividend was paid out.

H2: There is a statistically significant correlation between the paid-out dividend and the value of the financial parameters in the year of the dividend payout.

H3: There isn't any statistically significant correlation of the Dividend Payout Ratio with the financial parameters of the company's operation in the year for which the dividend was paid out.

H4: There isn't any statistically significant correlation of the Dividend Payout Ratio with the financial parameters of the company's operation in the year of the dividend payout.

The financial parameters for which the hypotheses were verified are:

- operating income,

- net profit,

- cash flows,

- investment flows,

- cash,

- assets,

- fixe capital,

- equity,

- return of Assets ROA,

- return on Equity ROE.

The analysis covered financial data of companies quoted on Warsaw Stock Exchange in the period 2002-2013, whereas financial companies were excluded. The analysis was limited to companies belonging to the index WIG20, mWIG40 and sWIG80.

The research was carried out in three stages:

1. Definition and selection of dividend companies. The selection criteria were specified in the way enabling to select companies for which it was possible to calculate correlation coefficients.

2. Analysis of the correlation between the amount of the paid-out dividend and financial parameters specified in the hypotheses, describing the companies' operations. The correlation was studied by means of Pearson's linear correlation coefficient. The study covered the relationships between dividends paid out in the year "n" and data from the financial report from the year "n- 1 " and data from the financial report from the year " $n$ ".

3. Analysis of the correlation of the factor of the share of the paid-out dividend in the profit to be distributed (hereinafter referred to as the dividend payout ratio) with selected parameters describing the companies' operations. Methodology of the study of the correlation - as in stage 2 . 


\section{Research results}

\subsection{Selection of companies for the study}

The prerequisite for the study of relationships between the amount of the paid-out dividend and the selected financial parameters must be choosing companies which relatively regularly pay out dividends for the sake of the analysis. In this case, it is insufficient to apply the criterion used by Warsaw Stock Exchange to select dividend companies. According to this criterion, a dividend company is a company which during the last 5 years paid out the dividend at least for 3 years. The 3-year period of the dividend payout is practically too short as the basis for calculating Pearson's correlation coefficient. On the other hand, the number of companies regularly paying out dividends is rather low on the Polish stock exchange, which renders it impossible to limit the analysis to companies which pay out dividends in a long period of time. For these reasons, basing on preliminary calculations, it was assumed that the study would cover only those companies which (in the 12-month period subject to the analysis) had paid out dividends at least 5 times.

As a result of adopting the criterion referred to above, a study sample was obtained, consisting of 48 companies, 8 of which were quoted in WIG20, 15 in mWIG40 and 25 in sWIG80. In the analyzed period, these companies had paid out the dividend 7.9 times on average, whereas this mean differed in the individual groups only to a minor extent (7.9, 7.2 and 8.3, respectively). Three of the examined companies (Orange, Apator and Dębica) had paid out dividends in all the analyzed years and the next eight companies paid out the dividend at least 10 times in the analyzed period. It should be taken into consideration that not all companies subjected to the analyses were quoted on the capital market throughout the entire analyzed period of time.

\subsection{Correlation of the amount of the paid-out dividend with selected financial parameters of the company's operations}

The initial synthetic image of the relationship between the paid-out dividend and the selected financial parameters of the companies' operations is presented in Figure 1. The figure depicts medians of coefficients of the correlation of the dividend with selected values which describe the company's operations during the previous year for all the companies studied. As it can be seen, these relationships are not strong, which means that the amount of the dividend depends on the financial and property-related coefficients of companies' operations only to a minor extent. The amount of the dividend partly derives from the scale of the company's operations (its size). The strongest relationships occur between the dividend and the parameters which describe the company's assets. Such parameters comprise most of all of the book value of assets, constant capital and equity. The median of coefficients of the correlation of these parameters with the paid-out dividend exceeds 0.5 . What is 
characteristic, the parameters which describe fixed foundations for the company's operations expressed in the constant capital or equity are more significant. The correlation between the dividend and these two parameters is clearly higher (over 0.6). The sum of the assets, on the other hand, indicates not only the value of the assets, as it is also influenced by the policy of shaping dues and liabilities, or even by the accounting policy. Hence the seemingly obvious correlation between the value of the assets and the dividend is slightly lower (0.57).

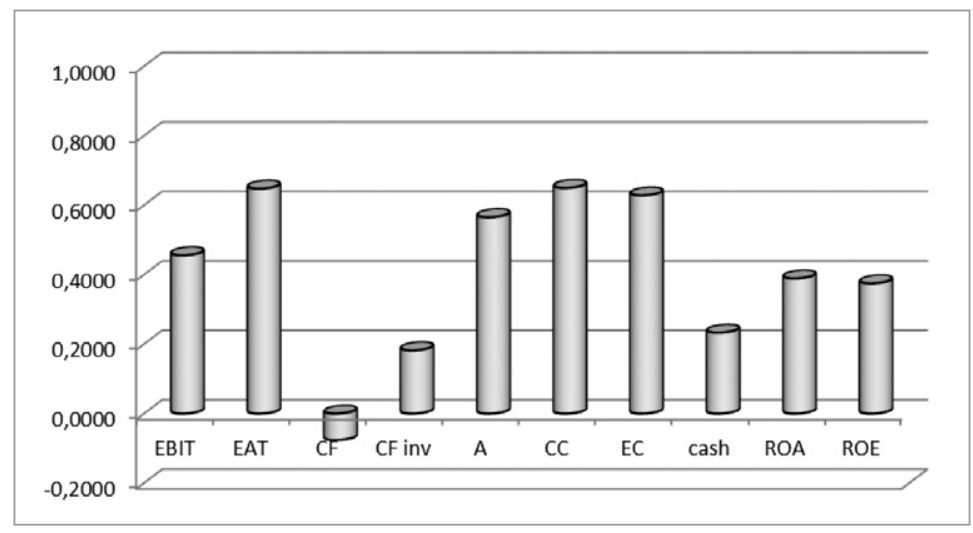

Figure 1. Pearson's correlation coefficients (median) - correlation between the amount of the paid-out dividend and parameters of the operations of the examined companies in the year for which the dividend was paid out

EBIT - operating income; EAT - net profit; CF - total cash flow ; CFinv - investment flows; A - assets; CC - constant capital; EC - equity capital; cash - cash.

Source: the author's own work.

Since the dividend is always a part of the net profit (the dividend can also be paid out from the profit from the previous years; however, such events occur relatively rarely; therefore, it can be assumed that such events do not have a significant impact on the results of the calculations, these two values are also positively correlated with each other in an obvious way. However, this correlation is not very high, the median of the correlation coefficients equals only 0.648 and is even slightly lower than the median of the correlation coefficients between the dividend and the constant capital (0.650). Operating income, on the other hand, influences the amount of the dividend only to a minor extent (indicator 0.46 ). A relatively low degree of the dependence of the dividend on the financial result obtained simultaneously indicates considerable variability of the Dividend Payout Ratio.

The net profit is an absolute measure of the financial result in the same way in which the assets, equity and constant capital are absolute measures of the company's property. The correlation of all these values with the dividend is much higher than the correlation with relative measures. This means that it is the strength of a company, not its effectiveness, that gives rise to the willingness to share the profit with its owners. 
The analyzed data clearly contrast the views that emphasize a strong relationship of the generated cash flow with the dividend [Brigham, Houston, 2005, p. 210-211]. On the contrary, if there is any relationship between these values, it is actually reversed. The median of coefficients of correlation between the dividend and the cash flow is close to zero, but it is negative (median -0.08 , average - 0.04 ). Any relationship of the dividend can be noticed only with the cash held, but event this relationship cannot be recognized as a significant one $(0.23)$.

Provisions of the dividend policies of numerous publicly held companies contain information on the relationship between the amount of the dividend and the need to satisfy their investment demands. This should mean that the increase of investment outlays should result in the limitation on the amount of the dividend. Investment outlays are reflected in cash flow from investment activities. In compliance with the principles referred to above, cash flow from the investment activities should have a negative correlation with the amount of the dividend. Since investment outlays are presented as negative values, a relevant correlation coefficient should have a positive value. Indeed, the median of the calculated correlation coefficients is positive in this case; however, its value is very low (0.18). Therefore, although one can observe a certain negative relationship between these parameters of the company's operation, it is insignificant.

Researchers [Bulan, Subramanian, 2009] have pointed out that dividends are willingly paid out by large companies exhibiting most of all high profitability in relation to the contributed capital which do not have any considerable investment options. Furthermore, according to the authors, the dividend policy is determined by the relation between the ROE parameter and the capital cost. Similar conclusions were reached by H. DeAngelo, L. DeAngelo, R.M. Stulz [DeAngelo, DeAngelo, Stulz, 2006, pp. 227-254] and D. Denis and I.Osobov [after: Kowerski, 2011, p. 177]. In their opinion, the chances to have the dividend paid out grow with the growth of among other things - the ROE parameter. Also, research carried out by E.F. Fama and K.F. French [2001, pp. 3-43] confirms that the dividend payouts depend on - without limitations - the company's profitability. The calculations conducted do not allow us to reach such conclusions. In the examined companies, the dividend depends on the profitability of the company's operations only to a minor extent. Although this relationship is stronger than in case of cash flow, still it is not a significant one. What is characteristic, the level of the median of $t$ coefficients of the correlation between the dividend and ROA (0.39) and ROE (0.38) is similar.

A question arises whether the described relationships (or lack thereof) are connected with the size of the company. Classifying the company in the stock exchange index (WIG20, mWIG40, sWIG80) was assumed as a determinant of the size of a company. It should be pointed out that the size of a company influences not only the scale of its operations (and consequently its dividend), but also the way the company is managed, including the scope of the owners' impact on dividend-related decisions. The smaller the company, the more often a situation of a strong impact of the main shareholder on the most fundamental decisions of the company occurs. 
Pobrane z czasopisma Annales H - Oeconomia http://oeconomia.annales.umcs.pl

Data: 26/04/2023 02:51:29

IDENTIFICATION AND ANALYSIS OF FINANCIAL DETERMINANTS OF THE DIVIDEND POLICY...

Table. 1. Pearson's correlation coefficient in the break down into indexes (median) - correlation between the amount of the paid-out dividend and the parameters of the operations of the examined companies in the year for which the dividend was paid out

\begin{tabular}{|l|c|c|c|c|}
\hline \multirow{2}{*}{ Operation parameter } & \multirow{2}{*}{ Total } & \multicolumn{2}{|c|}{ Companies which belong to the index } \\
\cline { 2 - 5 } & & WIG20 & mWIG40 & sWIG80 \\
\hline Operating income & 0.456 & 0.667 & 0.392 & 0.375 \\
\hline Net profit & 0.648 & 0.698 & 0.667 & 0.579 \\
\hline Cash flow & -0.076 & -0.038 & 0.038 & -0.087 \\
\hline Investment flows & 0.182 & 0.318 & 0.044 & 0.208 \\
\hline Assets & 0.566 & 0.423 & 0.649 & 0.449 \\
\hline Constant capital & 0.650 & 0.431 & 0.645 & 0.659 \\
\hline Equity & 0.628 & 0.429 & 0.699 & 0.650 \\
\hline Cash & 0.233 & 0.299 & 0.267 & -0.029 \\
\hline ROA & 0.389 & 0.507 & 0.446 & 0.321 \\
\hline ROE & 0.375 & 0.495 & 0.266 & 0.341 \\
\hline
\end{tabular}

Source: the author's own work.

The data presented in Table 1 indicates a significant discrepancy between the strengths of the impact of individual parameters of the company's operations on the amount of the dividend. It can be observed that the relations described above are nearly fully confirmed for medium enterprises (mWIG40). The strength of the correlation between the dividend and individual parameters is very similar to the median calculated for all the examined companies. The dividend depends most of all on the generated profit and the size of the company, determined by the value of the equity capital and constant capital, as well as, to a slightly lesser extent, by the book value of the assets. In these cases medians of the correlation coefficients are slightly higher than the ones valid for the entire population examined. The only essential feature specific for this group of companies is a different relation between the dividend and the profitability of the company's operations. The relation between the dividend and the return on assets (ROA) is stronger than between the dividend and the return on equity (ROE). In the latter case the correlation with the dividend is lower than for all the companies. It results from irregular changes in the value of the equity capital and assets, which signifies a considerable variability of the financing structure in medium companies.

In large companies (WIG20), the amount of the dividend to the greatest extent depends on the generated income, whereas in this case, the dependence on the net profit goes hand in hand with the dependence on the operating income. While the correlation of the dividend with the profit is obvious, the simultaneous significant correlation with the operating income signifies a similar variability of both these measures of the financial result. Profits of the largest companies are, therefore, generated predominantly in the area of the operating activity. Not only is it a sign of an appropriate structure of the financial result, but it also provides a stable foundation for dividend profits for investors.

Changes of the dividend in the largest companies depend on the changes of the value of the company's property only to a minor extent. The median of the correlation 
coefficients of parameters which describe the company's property and the dividend hovers at the level of 0.4 , which is lower than for all the companies. A large number of companies result in the fact that the increase of the property, if any, does not constitute a sufficient stimulus for the dividend to be increased. In this group of companies, on the other hand, the correlation between the dividend and the results measured by relative measures is much clearer. The median of coefficients of the correlation between the dividend and the indicators of the operations profitability reaches 0.5 , which is a clearly higher result than in the remaining groups of companies. Perhaps it is connected with the application of economic analyses, rising together with the rise of the size of companies, which induces to make decisions on the basis of ratios rather than absolute values.

Also in large companies, contrary to theories, the cash flow value does not translate to the paid-out dividend in any way. On the other hand, it is the only group of companies where a slight dependence of the dividend on the investment outlays incurred can be observed. The median of coefficients of the correlation between the dividend and the investment cash flow equals 0.32 ; therefore, it can be assumed that in these companies investment demands influence investment-related decisions in some way.

Definitely, the lowest level of correlation between the dividend and the parameters which describe the company's operations is demonstrated by small companies (sWIG80). It can be observed that relations in this group of companies are similar to the ones described for the entire examined population, but only as far as the classification of the strength of impact of individual parameters on the dividend is concerned. These relations are, however, much weaker. The highest correlation is exhibited between the dividend and the equity capital, the net profit and the constant capital, but in none of the cases the median of the correlation coefficients reaches 0.5 . Also other calculated correlation coefficients are lower in comparison to the other groups of companies. This means that the dividend policy of small companies is based on non-financial determinants. It confirms the specific role of the main shareholders in the process of making dividend-related decisions, which increases as the size of the company drops, which has been referred to above. Although the main shareholder plays a decisive role in the shaping the dividend policy in each company, in small companies, the main shareholders are usually natural persons. In such companies, the probability that dividend-related decisions will be made not on the basis of the financial and property-related standing of the company, but on the needs of the main shareholder, is higher. The presented data does not allow us to deny this phenomenon, although they do not provide the basis for a positive verification of the claims referred to above.

An analysis of medians of the correlation coefficients gives a synthetic initial image of correlation relationships of the examined parameters of the companies' operations. Such an analysis does not, however, allow us to clearly confirm the existence or lack of such relationships. The number of observations for individual companies is variable and hovers between 5 to 12 . Hence a variable - for individual companies - number of degrees of freedom $d f$ (from 3 to 10) and consequently the 
significance of Pearson's correlation coefficients calculated for the companies should refer different limit values. For this reason, the study was completed with an analysis of the described correlations observed in individual companies.

Table 2. Companies in which there is a statistically significant correlation between the amount of the paid-out dividend and selected parameters of operations of the examined companies in the year for which the dividend was paid out

\begin{tabular}{|l|c|c|c|c|}
\hline \multirow{2}{*}{ Operation parameter } & \multicolumn{2}{|c|}{ Positive correlation } & \multicolumn{2}{c|}{ Negative correlation } \\
\cline { 2 - 5 } & $\begin{array}{c}\text { Number of } \\
\text { companies }\end{array}$ & \% of companies & $\begin{array}{c}\text { Number of } \\
\text { companies }\end{array}$ & \% of companies \\
\hline Operating income & 13 & 27.1 & 2 & 4.2 \\
\hline Net profit & 16 & 33.3 & 1 & 2.1 \\
\hline Cash flow & 1 & 2.1 & 0 & 0 \\
\hline Investment flow & 2 & 4.2 & 1 & 2.1 \\
\hline Assets & 15 & 31.3 & 1 & 0 \\
\hline Constant capital & 19 & 39.6 & 0 & 0 \\
\hline Equity capital & 19 & 39.6 & 0 & 0 \\
\hline Cash & 9 & 18.8 & 1 & 2.1 \\
\hline ROA & 7 & 14.6 & 1 & 2.1 \\
\hline ROE & 8 & 16.7 & 0 & 0 \\
\hline
\end{tabular}

Source: the author's own work.

The data presented in Table 2 confirms the conclusions resulting from the analysis of medians of the correlation coefficients. The only operation parameters which determine the amount of the dividend in a larger group of companies are of a property-related character. In a large part of the companies (nearly $40 \%$ ), the paid-out dividend depends most of all on the accumulated capital. Characteristically enough, in this case, it is not the current profit generated by the companies that decides about it (significant relation in $33.3 \%$ of companies), but the total value of the capital. Therefore, the total accumulated value of the companies' resources should be recognized as the determinant of the amount of the dividend. It should be emphasized that it is about the value of the company's property to a lesser extent than it is about the value of the capital (assets are a significant determinant in $31.3 \%$ of the examined companies). The current results constitute a determinant of the dividend payout to the extent they are a part of the generated potential of the company.

The conducted calculations clearly indicate that one cannot point out to any significant relation between the paid-out dividend and cash flow. It refers to the total cash flow, as well as to the investment cash flow. There are only a few companies where the coefficient of the correlation between the dividend and cash flow has a statistically significant value. Similarly, one cannot talk about a significant relation between the dividend and the collected cash. On the other hand, the evaluation of the relation between the dividend and the collected cash is not very reliable. The balance sheet demonstrates the condition of cash as of the end of the year. This condition does not have to well reflect cash resources available in a year's scale, all the more that cash is the most fluid resource of each enterprise. 
The number of companies where the dividend is determined by the profitability of the companies' operations is low, too. Such a relation is demonstrated in a bit more than ten per cent of the examined companies. A successful result of the company's operations does not have any impact on the inclination to increase the paid-out dividend. On the other hand, according to some researchers [Tuzimek, 2013, p. 294], companies with high values of ROE which do not pay out dividends can be perceived positively by investors, because refraining from the transfer of profits to shareholders can generate positive cash flows in the future from highly profitable projects and thus bring about the share price appreciation.

Even if the aforementioned principles were taken into account in companies, it cannot be demonstrated in the statistical data as it would mean that companies which reach low return levels would have to pay out high dividends. At the same time, a negative correlation between the dividend and the return rate would be demonstrated. Apart from single instances, it is, however, impossible, because in a longer period, low return simultaneously means the lack of cash for the dividend increase.

Few identified cases of a negative correlation between the dividend and some financial parameters of the companies' operations are due to different reasons and must be analyzed individually. For example, in Agora there is a statistically significant negative correlation between the dividend and the operating income and a bit lower negative correlation (on the verge of statistical significance) with the net profit. This results from the dividend policy applied by the company, which assumes maintaining a constant level of the dividend. With the simultaneous considerable fluctuations of the operating income and the net financial result, it gave rise to the occurrence of a negative correlation with the dividend.

The analyses presented above point out to a low level of dependence of the dividend from the condition and operations of an enterprise in a period for which the dividend is paid out. Since, however, the decision to pay out the dividend is taken several months after the end of the year, it can be made taking into account the conditions occurring in the period between the balance year and the moment when the decision about the profit distribution is made. Therefore, correlations between the amount of the dividend and the results of the accounting year during which the dividend-related decision was made were also analyzed (Figure 2).

The dependence of the paid-out dividend from financial results of the next year (the year of the dividend payout) are very diversified in the three groups of companies; therefore, an analysis of medians of the correlation coefficients calculated for the examined population of the companies does not provide us with any valuable knowledge. A general statement pertaining to these values could be contained in an opinion according to which the relation between the dividend and the current results of companies is much lower.

The most spectacular are values of coefficients of the correlation between the dividend and parameters which describe the operations of the largest companies (from the WIG20 index). No financial parameter determining the value of the div- 


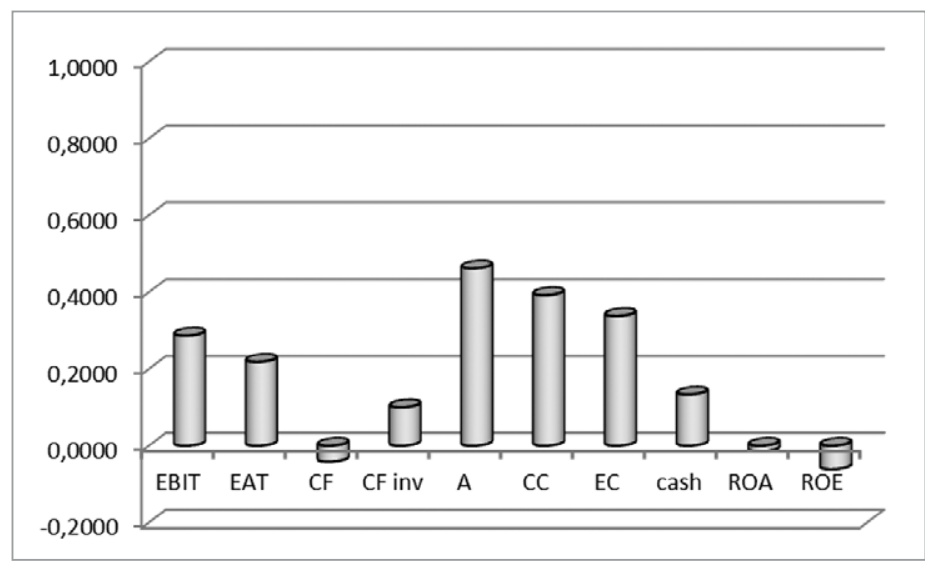

Figure 2. Pearson's correlation coefficients (median) - correlation between the amount of the paid-out dividend and t operation parameters of the examined companies in the year of the dividend payout

EBIT - operating income; EAT - net profit; CF - total cash flow; CFinv - investment flows; A - assets; CC - constant capital; EC - equity capital; cash.

Source: the author's own work.

idend paid out by these companies was found (Table 3). It has no relation with the financial result, nor the financial standing of the company. On the contrary, medians of coefficients of the correlation with cash flow or with the equity capital demonstrate negative values. Nevertheless, it is quite justified, as the dividend payout constitutes a negative cash flow in a given year, so the higher the dividend, the lower the cash flow value in a given year. Similarly, a paid-out dividend results in the decrease of the equity capital. Therefore, the signs of the calculated correlation coefficients are correct.

Table 3. Medians of Pearson's correlation coefficients in the breakdown into indexes - correlation between the amount of the paid-out dividend and parameters of operations of the examined companies in the year of the dividend payout

\begin{tabular}{|l|c|c|c|c|}
\hline \multirow{2}{*}{ Operation parameter } & \multirow{2}{*}{ Total } & \multicolumn{2}{c|}{ Companies which belong to the index } \\
\cline { 3 - 5 } & & WIG20 & mWIG40 & sWIG80 \\
\hline Operating income & 0.287 & 0.179 & 0.400 & 0.198 \\
\hline Net profit & 0.219 & 0.034 & 0.154 & 0.500 \\
\hline Cash flow & -0.041 & -0.219 & -0.068 & 0.018 \\
\hline Investment flow & 0.100 & -0.014 & -0.061 & 0.272 \\
\hline Assets & 0.462 & 0.072 & 0.601 & 0.523 \\
\hline Constant capital & 0.392 & -0.003 & 0.303 & 0.506 \\
\hline Equity capital & 0.338 & -0.108 & 0.403 & 0.367 \\
\hline Cash & 0.134 & 0.040 & 0.357 & 0.155 \\
\hline ROA & -0.015 & -0.096 & -0.103 & 0.058 \\
\hline ROE & -0.061 & -0.145 & -0.140 & 0.162 \\
\hline
\end{tabular}

Source: the author's own work. 
In the above context, the observable relations between the dividend on one hand and financial results and the financial standing on the other, demonstrated in the remaining analyzed groups of companies, are more difficult to justify. Higher medians of the correlation coefficients are demonstrated in respect of parameters which describe the value of the company's property - its capital and assets, rather than the measures of the financial result. Characteristically enough, in the group of the smallest companies (sWIG), medians of the calculated correlation coefficients in respect of the previous year and in respect of the year of the dividend payout, hover at a similar level. This can prove not so much an equal impact of the results reached in both periods on the dividend-related decisions, as the relative stability of financial results and value of these companies' property.

The results of the calculations indicate that the amount of the paid-out dividend does not have any significant impact on the profitability of the company's operations; medians of coefficients of the correlation of the dividend with ROA and ROE are close to zero. Simultaneously, negative signs of the correlation coefficients in the group of large companies and in the group of medium companies can prove a certain negative impact of the dividend on the effects of the company's operations. A low value of the correlation of the dividend with the return reached in the payout year could be recognized as a satisfactory result, considering the fact that a correct profit division is to have a positive impact on profitability, whereas "correct" can stand for a high or low dividend, depending on a specific situation. This should not be governed by a simple principle and it means that the correlation of these two values should not take place at all.

In compliance with the theory of the hierarchy of financing sources, enterprises which implement investment projects, try to finance them firstly from the profit they generate [Bulan, Zhipeng, 2007]. Therefore, investments of companies which allocate internal capitals should have a negative impact on the possibility to pay out the dividend. Thus the lack of correlation of the dividend with the investment flows in the next year is rather disturbing. The calculation results constitute an obvious denial of the principles presented in the dividend policies of a large part of companies. High investment outlays in the coming period should be connected with the decrease of the dividend paid out for the previous year. A negative (although close to zero) median of the correlation coefficients in groups of companies from WIG 20 and mWIG40 is the evidence of completely different decisions of investors. Investment demands do not constitute a condition for decreasing the investors' requirements concerning the dividend. Such a relation occurs only in the group of the smallest companies.

A detailed analysis of correlation coefficients for individual companies in the examined population confirms the conclusions drawn from the analysis of the coefficients' medians. Only in a small group of companies, statistically significant correlations of the amount of the paid-out dividend with financial parameters which describe the company's operation in the year of the dividend payout were identi- 
fied. Changes of the paid-out dividend are most often determined by changes in the financial standing of the company; this, however, does not concern a large group of companies. A statistically significant correlation of the dividend with the value of the assets was identified in $27.1 \%$ of the companies, and respective correlations with the constant capital and equity capital were identified in $27.1 \%$ and $25.0 \%$ of the examined companies.

The other parameters of the companies' operations in the year of the dividend payout are rarely significantly dependent on the amount of the dividend. In particular, a statistically significant correlation of the dividend with ROE occurred only in 7 companies, whereas in two cases it was a negative correlation. As a result, hypotheses on the relations between financial parameters of a company's operations and the dividend paid-out in a specific year should be rejected. It does not concern only those parameters which describe the size of the company's property. Their dependence on the paid-out dividend cannot be unambiguously evaluated.

\section{Correlation of the Dividend Payout Ratio with selected financial parameters of a company's operations}

The dependence of the dividend on the results of companies can be interpreted in two areas. Relations between the dividend and results expressed in absolute values are different if one considers relative indicators. If it can be assumed that the results achieved by a company are determinants of the amount of the dividend paid-out, such a statement with reference to the Dividend Payout Ratio (understood in this case as a quotient of the dividend for a specific year and the net profit in the same year) is burdened with a considerable risk. Coefficients of the correlation of the Dividend Payout Ratio with parameters which describe companies' operations are clearly lower. Significantly enough, these coefficients are largely negative. In simple terms, it means that the better results are achieved by a company, the lower its inclination to distribute the profits among its investors. It concerns such fundamental measures of the financial result as operating income, net profit or cash flow. Obviously, a better financial result allows to pay out a higher dividend, adopting a lower Dividend Payout Ratio. It can constitute an explanation of the demonstrated negative correlation of these values. It concerns practically all groups of the examined companies.

The Dividend Payout Ratio is in no way connected with changes in the value of the company's property, medians of respective correlation coefficients are close to zero (Figure 3). Only in the group of the smallest companies medians of these coefficients are slightly higher, and the correlation is clearly positive (Table 4). In small companies the improvement of their property-related situation is more noticeable, which perhaps translates into the increasing inclination to pay out the profit as such companies develop. 


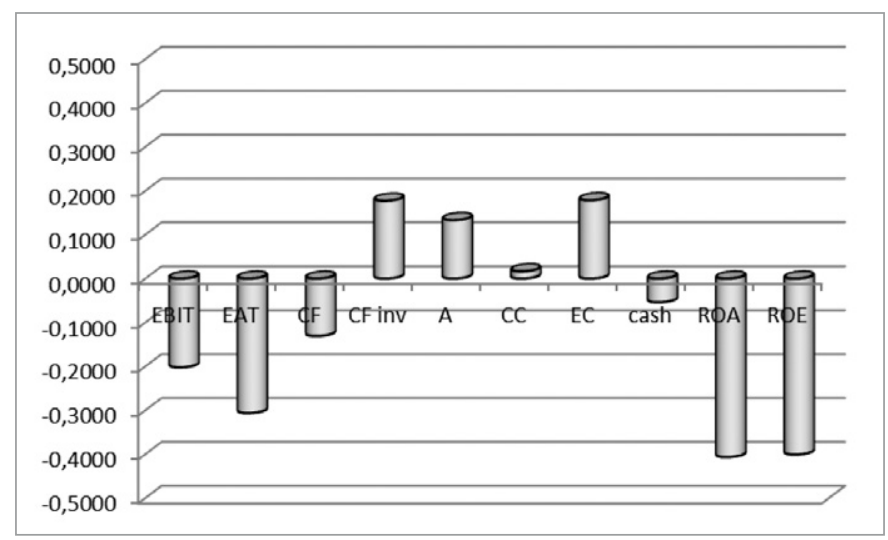

Figure 3. Medians of Pearson's correlation coefficients in the breakdown into indexes - correlation of the value of the Dividend Payout Ratio and operations parameters of the examined companies in the year for which the dividend was paid out

EBIT - operating income; EAT - net profit; CF - total cash flow; CFinv - investment flow; A - assets; CC - constant capital; EC - equity capital; cash.

Source: the author's own work.

Table 4. Medians of Pearson's correlation coefficients in the breakdown into indexes - correlation of the value of the Dividend Payout Ratio and operation parameters of the examined companies in the year for which the dividend was paid out

\begin{tabular}{|l|c|c|c|c|}
\hline \multirow{2}{*}{ Operation parameter } & \multirow{2}{*}{ Total } & \multicolumn{2}{|c|}{ Companies which belong to the index } \\
\cline { 2 - 4 } & & WIG20 & mWIG40 & sWIG80 \\
\hline Operating income & -0.202 & -0.167 & -0.109 & -0.264 \\
\hline Net profit & -0.306 & -0.297 & -0.402 & -0.322 \\
\hline Cash flow & -0.130 & 0.087 & -0.207 & -0.139 \\
\hline Investment flow & 0.178 & 0.230 & 0.177 & 0.206 \\
\hline Assets & 0.133 & -0.092 & 0.008 & 0.325 \\
\hline Constant capital & 0.017 & -0.126 & -0.075 & 0.296 \\
\hline Equity & 0.179 & -0.022 & 0.067 & 0.269 \\
\hline Cash & -0.054 & 0.158 & -0.054 & -0.261 \\
\hline ROA & -0.406 & -0.368 & -0.371 & -0.349 \\
\hline ROE & -0.400 & -0.422 & -0.365 & -0.413 \\
\hline
\end{tabular}

Source: the author's own work.

It is difficult to explain negative relations between the Dividend Payout Ratio and cash. This relation is demonstrated mainly in smaller companies. Perhaps some immeasurable premises decide about it. The only explicit relation, on the other hand, occurs between the Dividend Payout Ratio and the return indicators (ROA and ROE). These correlations are not very strong, but they are clear enough. Significantly, these are negative relations and this principle occurs in all groups of companies. The higher the effectiveness of the company's operation in the previous year, the smaller part of the profit will be transferred to investors. Most probably, this relation results 
from the investors' willingness to multiply the profit. If a company generates a high income rate, one can hope for further good effects of its operations. In such a situation, investors are not interested in the dividend payout. It is a sign of an optimistic perception of the future of companies which today function well. Verification of such a way of perceiving investments can be the analysis of the correlation of the dividend with the profitability ratio of companies reached in the year of the dividend payout.

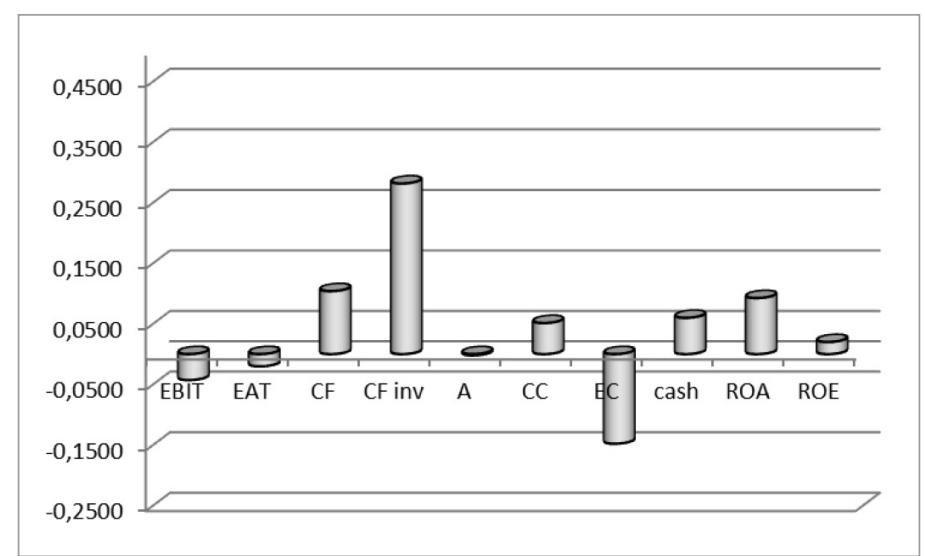

Figure 4. Pearson's correlation coefficients (median) - correlation of the Dividend Payout Ratio and operations parameters of the examined companies in the year of the dividend payout

EBIT - operating income; EAT - net profit; CF - total cash flow; CFinv - investment flow; A - assets; CC - constant capital; EC - equity capital; cash.

Source: the author's own work.

Calculations do not point out to the existence of any relation between the Dividend Payout Ratio and profitability reached in the year of the dividend payout. Capital left in profitable companies did not contribute to the generation of appropriate profits during the next year (Figure 4). A positive sign of the correlation coefficient would rather point out to a reverse effect. The situation at the correlation analysis in the breakdown into size groups of companies is slightly different (Table 5). In large and medium companies, the median of the majority of correlation coefficients is negative, which can confirm a positive impact of leaving the capital in the company, regardless. Very low values of the correlation coefficient (median ca. 0.1) do not allow, however, to put forward theses of the kind.

Analyzing coefficients of the correlation of the Dividend Payout Ratio with parameters which describe a company's operations in the year of the dividend payout, one notices a practical lack of any significant relations. It should be pointed out that these coefficients can be interpreted in two ways. On one hand, they can indicate an impact (or lack thereof) of the dividend payout on the company's operations in a specific year. On the other hand, they can point out to the impact of the owners' predictions concerning the company's operations in a specific year on the dividend-related 
Pobrane z czasopisma Annales H - Oeconomia http://oeconomia.annales.umcs.pl

Data: 26/04/2023 02:51:29

Table 5. Median of Pearson's correlation coefficients in the breakdown into indexes - correlation of the amount of the dividend payout and operation parameters of the examined companies in the year of the dividend payout

\begin{tabular}{|l|c|c|c|c|}
\hline \multirow{2}{*}{ Operation parameter } & \multirow{2}{*}{ Total } & \multicolumn{3}{c|}{ Companies which belong to the index } \\
\cline { 3 - 5 } & & WIG20 & mWIG40 & sWIG80 \\
\hline Operating income & -0.043 & -0.014 & -0.043 & -0.059 \\
\hline Net profit & -0.020 & -0.006 & -0.250 & 0.032 \\
\hline Cash flow & 0.104 & 0.069 & -0.196 & 0.220 \\
\hline Investment flow & 0.282 & 0.105 & 0.163 & 0.427 \\
\hline Assets & -0.002 & -0.315 & -0.289 & 0.212 \\
\hline Constant capital & 0.051 & -0.092 & -0.287 & 0.297 \\
\hline Equity & -0.148 & -0.243 & -0.335 & 0.306 \\
\hline Cash & 0.060 & 0.154 & -0.034 & 0.051 \\
\hline ROA & 0.093 & -0.041 & -0.070 & 0.093 \\
\hline ROE & 0.029 & -0.085 & -0.120 & 0.050 \\
\hline
\end{tabular}

Source: the author's own work.

decisions. A very low value of medians of the calculated coefficients indicates a lack of the aforementioned relations in the first as well as in the second area. Only investment cash flow exhibits a noticeable, although weak, correlation with the Dividend Payout Ratio. It is indicated by the impact of the planned investment operations on the manner in which the profit is distributed. The higher investment layouts are planned for a specific year, the larger part of the profit is left in the company by its owners.

The coefficients discussed above exhibit considerable differences within individual size groups of companies. Medians of correlation coefficients calculated in individual groups are clearly higher than for the entire examined population. It is a result of a noticeable discrepancy between the smallest companies and the remaining ones. The signs of most calculated correlation coefficients in both groups are opposite, which causes their "neutralization" for the entire population. The smallest companies exhibit positive relations between the Dividend Payout Ratio and nearly all the analyzed parameters. In medium companies, medians of nearly all coefficients are negative. In case of the largest companies, correlation coefficients have various signs, however, the negative ones have higher absolute values.

The positive correlations observed in small companies may point out to a positive effect of the dividend payout. Nevertheless, it is more probable that owners of small companies pay out a higher dividend, predicting a more successful future for their company, or are really good at predicting the nearest future. A relatively high median of the coefficient of the correlation with investment flow is worth noticing. Smaller companies, which are not so broadly held, find it easier to condition the dividend payout on the investment outlays planned for a specific year. Such a positive correlation is also present in other groups of companies, but it is explicitly lower.

In medium companies, the Dividend Payout Ratio exhibits slight negative relations with the value of the company's property and its financial result, whereas in large companies - only with the property. The dividend policy in these groups of 
companies seems to be less correct than in small companies. It can have its impact on the clash of interests of groups of owners. Unambiguous conclusions, however, call for more detailed analyses of the situation in these groups of companies.

All comments referring to the determinants of the Dividend Payout Ratio in the examined companies can pertain exclusively to the directions of certain relations. The strength of these relations is very low. The analysis of the correlation coefficients calculated in individual companies points out to a practical lack of statistically significant correlations in this area. The number of companies where a significant correlation with individual parameters was identified, constitutes only several per cent of the examined population ( 9 companies at the most). It should be recognized that these are cases that constitute certain aberrations.

Two phenomena, however, are worth emphasizing. First of all, no company exhibits a statistically significant correlation of the Dividend Payout Ratio with cash flow in the year for which the dividend was paid out. The inclination to distribute the profit does not depend on the generated cash flow. Secondly, the relation between the Dividend Payout Ratio and the profitability of the company's operations is truly interesting. As many as 9 companies (18.8\% of the examined population) exhibit a statistically significant negative correlation of the Dividend Payout Ratio with ROE for the previous year. A similar negative correlation with ROE reached in the year of the dividend payout was not observed in any of the examined companies, and at the same time 5 companies exhibited a positive correlation in this respect. Therefore, high profitability favours leaving the capital in the company, which, however, does not translate to a positive effect of its operations in the subsequent year. Thus, dividend-related decisions of companies prove to be irrational. Nevertheless, one needs to bear in mind that the scale of the described correlation is rather small, so it only indicates a certain direction of the relations, and not a rule.

\section{Conclusions from the study}

The study presented herein aimed at the identification of internal financial determinants of the dividend payout in publicly held companies. None of the determinants of the dividend policy specified in the subject literature found an explicit confirmation in the study. Simultaneously, the study negates the impact of a number of indicated factors on the companies' inclination to pay out the dividend. The study covered four areas of relations of the dividend with the selected financial parameters in which the hypotheses were verified. The results of the verification can be presented as follows:

1. The hypothesis on the correlation between the value of the paid out dividend and financial parameters of a company's operations in the year for which the dividend was paid out was rejected in the part concerning total cash flow, investment flow, cash, ROA and ROE. Correlation with the remaining analyzed parameters was partly confirmed. 
2. The hypothesis on the correlation of the paid out dividend with financial parameters of a company's operations in the year of the dividend payout was rejected in the part pertaining to the operating income, net profit, total cash flow, investment flow, cash, ROA and ROE. Correlation with the remaining analyzed parameters (assets, constant capital, equity capital) was partly confirmed.

3. The hypothesis on the lack of correlation of the Dividend Payout Ratio with financial parameters of the company's operation in the year for which the dividend was paid out, cannot be rejected with respect to any of the analyzed parameters. The results point out to slight negative correlations with the majority of the parameters, but they are not statistically significant.

4. The hypothesis on the lack of correlation of the Dividend Payout Ratio with financial parameters of the company's operation in the year of the dividend payout cannot be rejected with respect to any of the analyzed parameters.

\section{Conclusion}

Summarizing the study, it should be recognized that the dividend payout in Polish publicly held companies, both in terms of its value and the share of the dividend in the profit to be distributed, is not determined by any realistic financial results of the companies' operations. Correlations identified in a small share of the companies cannot explicitly confirm the existence of such relations even regarding some of the financial parameters. At the same time, the lack of relations between the scale of the dividend payout and the results achieved by the companies during the subsequent year points out to the lack of impact of the dividend policy adopted on the effectiveness of companies' operations. In the latter case, symptoms of a negative impact of the dividend payout are rather noticeable.

Considerable discrepancies between the conclusions of the study presented herein and theories and research conducted in other centres point out to the need to continue the process of results verification. The authors' intention is to carry out a similar study using different statistical tools. Another direction of our pursuits will be an analysis of possible determinants of the dividend payout of a dynamic nature, basing on the level of the parameters' changeability. Qualitative determinants of the dividend policy are being searched for at the same time.

\section{Bibliography}

Brigham E.F., Houston J.F., Podstawy zarzadzania finansami, t. 2, PWE, Warszawa 2005.

Bulan L., Subramanian N., The Firm Life Cycle Theory of Dividends, 2009, http://people.brandeis.edu/ 1bulan/Book_Chapter.pdf [access: 28.02.2015].

Bulan L., Zhipeng Y., The Pecking Order of Financing in the Firm's Life Cycle, 2007, http://69.175.2.130/ finman/Orlando/Papers/ThePeckingOrderofFinancingintheFirmsLifeCyclen2n. pdf [access: 24.02.2015]. 
DeAngelo H., DeAngelo L., Skinner D., Special Dividends and The Evolution of Dividend Signaling, "Journal of Financial Economics" 2000, No. 57, http://marshallinside.usc.edu/deangelo/Publications/ SpecialDiv.pdf [access: 11.02.2015].

DeAngelo H., DeAngelo L., Stulz R.M., Dividend Policy and the Earned/Contributed Capital Mix: a Test of the Life-Cycle Theory, "Journal of Financial Economics" 2006, Vol. 81, www.cob.ohio-state.edu/ fin/faculty/stulz/publishedpapers/Dividend\%20policy\%20and\%20the $\% 20$ earned $\% 20$ contributed $\% 20$ capital.pdf [access: 02.03.2015], DOI: http://dx.doi.org/10.1016/j.jfineco.2005.07.005.

Eije J.H. von, Megginson W.L., Flexibility of Dividend Policies and Shareholders'Returns in the European Union, 2006, http://ssrn.com/abstract=1342671 [access: 11.03.2015].

Fama E.F., French K.R., Disappearing Dividends: Changing Firm Characteristics or Lower Propensity to Pay?, "Journal of Financial Economics" 2001, Vol. 60, www.sciencedirect.com/science/article/pii/ S0304405X01000381/pdfft?md5=3dc1d70baca72a1dc98a59a4a4be8044\&pid=1-s2.0-S0304405X01000381-main.pdf [access: 01.03.2015], DOI: http://dx.doi.org/10.1016/S0304-405X(01)00038-1.

Horbaczewska B., Wyplaty dla akcjonariuszy a wycena akcji na rynku kapitatowym, CeDeWu, Warszawa 2012.

Jabłoński B. Znaczenie wyboru grup akcji do portfela inwestycyjnego na przykładzie Warszawskiej Giełdy Papierów Wartościowych w latach 1991-2009, [in:] U. Zagóra-Jonszta (ed.), Dokonania wspótczesnej myśli ekonomicznej. Znaczenie kategorii wyboru w teoriach ekonomicznych i praktyce gospodarczej, Wydawnictwo Uniwersytetu Ekonomicznego w Katowicach, Katowice 2010.

Kowerski M., Ekonomiczne uwarunkowania decyzji o wyplatach dywidend przez spótki publiczne, Konsorcjum Akademickie, Kraków 2011.

Lintner J., Distribution of Incomes of Corporations Among Dividends, Retained Earnings, and Taxes, "The American Economic Review" 1956, Vol. 46, No. 2, http://links.jstor.org/sici?sici=0002-8282\%28195605\%2946\%3A2\%3C97\%3ADOIOCA\%3E2.0.CO\%3B2-D [access: 22.02 .2015 ].

Sierpińska M., Dividend Policy in the Capital Companies, PWN, Warszawa - Kraków 1999.

Tuzimek R., Decyzje finansowe w spótkach giełdowych a wartość akcji, Szkoła Główna Handlowa. Oficyna, Warszawa 2013.

\section{Identyfikacja i analiza uwarunkowań finansowych polityki dywidend spółek notowanych na GPW w latach 2002-2013}

W artykule przedstawiono wyniki badań mających na celu określenie uwarunkowań finansowych polityki dywidendowej firm. Analizie poddano sprawozdania finansowe spółek notowanych na GPW w latach 2002-2013. Badanie z jednej strony koncentruje się na związku między kwotami wypłaconych dywidend i udziałem dywidendy w zysku do podziału, a $\mathrm{z}$ drugiej na wybranych parametrach finansowych opisujących działalność firmy w roku, dla którego dywidenda została wypłacona i w roku wypłaty dywidendy. Wyniki badań zostały skonfrontowane $\mathrm{z}$ teorią i wnioskami z badań prowadzonych w innych ośrodkach badawczych.

\section{Identification and Analysis of Financial Determinants of the Dividend Policy of Companies Quoted on Warsaw Stock Exchange in 2002-2013}

The article presents the results of research aiming at the identification of financial determinants of the dividend policy of companies. The analysis covered financial reports of companies quoted on Warsaw Stock Exchange in 2002-2013. The study focused on the relations between the amounts of the paid-out dividend and the share of the dividend in the profit to be distributed on one hand, and the selected financial parameters describing the company's operations in the year for which the dividend was paid-out and in the year of the dividend payout. The results of the study were confronted with the theory and conclusions from research carried out in other research centres. 